\title{
Multidisciplinary approach to identification of fishery production systems on the northern coast of Brazil
}

\author{
Bianca Bentes ${ }^{1,4}$, Victoria Judith Isaac ${ }^{1}$, Roberto Vilhena do Espírito-Santo ${ }^{1}$, Thierry Frédou ${ }^{3}$, \\ Morgana Carvalho de Almeida ${ }^{1}$, Keila Renata Moreira Mourão ${ }^{2}$ \& Flávia Lucena Frédou ${ }^{3}$ \\ ${ }^{1}$ Laboratório de Biologia Pesqueira e Manejo de Recursos Aquáticos, Instituto de Ciências Biológicas, \\ Universidade Federal do Pará - UFPA, Av. Perimetral, 2651, Guamá, CEP 66077-530, Belém, PA, Brazil \\ ${ }^{2}$ Laboratório de Dinâmica, Avaliação e Manejo de Recursos Pesqueiros, \\ Instituto de Geociências, Universidade Federal do Pará - UFPA, \\ Rua Augusto Corrêa, 1, Guamá, CEP 66075-110, Belém, PA, Brazil \\ ${ }^{3}$ Departamento de Pesca e Aquicultura, Universidade Federal de Pernambuco - UFPE, \\ Rua D. Manuel de Medeiros, sn, Dois irmãos, CEP 52171-900, Recife, PE, Brazil \\ ${ }^{4}$ Corresponding author: Bianca Bentes, e-mail: bianca@ufpa.br
}

BENTES, B., ISAAC, V.J., ESPÍRITO-SANTO, R.V., FRÉDOU, T., ALMEIDA, M.C., MOURÃO, K.R.M. \& FRÉDOU, F.L. Multidisciplinary approach to identification of fishery production systems on the northern coast of Brazil. Biota Neotrop. 12(1): http://www.biotaneotropica.org.br/v12n1/en/abstract?article+bn00612012012

Abstract: Artisanal fishing on the northern coast of Brazil is characterized by a set of different fishery modalities. Using a multidisciplinary approach, 20 fishery production systems were identified, with distinct characteristics regarding technology and purpose. The characteristics of each system were classified into five dimensions (ecological, economic, social, technological and political). Multidimensional scaling revealed that some of these 20 systems have greater similarities. Thus, a total of 10 groups were identified.

Keywords: production systems, fisheries, northern Brazil, fishery attributes.

BENTES, B., ISAAC, V.J., ESPÍRITO-SANTO, R.V., FRÉDOU, T., ALMEIDA, M.C., MOURÃO, K.R.M. \& FRÉDOU, F.L. Abordagem multidisciplinar para a identificação dos sistemas de produção pesqueira na costa Norte do Brasil. Biota Neotrop. 12(1): http://www.biotaneotropica.org.br/v12n1/pt/ abstract?article+bn00612012012

Resumo: A pesca artesanal na costa Norte do Brasil é caracterizado por um conjunto de modalidades de pesca diferentes. Utilizando uma abordagem multidisciplinar, 20 sistemas de produção pesqueira foram identificados, com características distintas em relação à tecnologia e finalidade. As características de cada sistema foram classificados em cinco dimensões (ecológicas, económicas, sociais, tecnológicos e políticos). A análise de escalonamento multidimensional revelou que alguns destes 20 sistemas têm semelhanças maiores. Assim, um total de 10 grupos distintos foram identificados.

Palavras-chave: sistema de produção, pesca, nordeste do Brasil, atributos pesqueiros. 


\section{Introduction}

Due to its huge amount of sediment and organic matter, the northern coast of Brazil sustains a high degree of biological production based fundamentally on demersal resources (Ministério do Meio Ambiente (Brasil 1997a). Thus, the exploitation of marine fishery resources is an important activity to the development of coastal populations. However, the disorderly growth of the fishing sector has led to a large number of conflicts regarding the use of such resources. Management measures have emerged in an attempt at establishing more sustainable solutions to this exploitation. Greater knowledge on fishery characteristics and their associations with society are necessary to the formulation of adequate regulatory measures and public policies regarding fishery modalities in the region.

In northern Brazil, as in other regions of the country, different fishery modalities and scales coexist - from subsistence fishing exercised for the sole objective of obtaining food for the fishermen's families to large-scale fishing involving vessels with sophisticated navigation and catch equipment capable of reaching distant oceanic areas (Brasil 1997b). Small-scale fishing lies between these two extremes and is characterized by its diversity in the use of catch methods, fishing power and finality (local, regional, national and international markets). Artisanal fishing modalities account for $90 \%$ of the fishery production of the northern coast of Brazil (Pará 2010).

For management purposes, commercial fisheries in Brazil are classically divided into two categories: industrial/semi-industrial and artisanal. Espírito-Santo (2002) and Braga (2002) subdivide the artisanal fleet of the region into two categories: small scale (vessels less than $12 \mathrm{~m}$ in length) and large scale (vessels larger than $12 \mathrm{~m}$ ). Industrial fisheries are easily identifiable from the specificity and economic importance in the generation of income, which facilitates their regulation and monitoring on the part of the authorities. However, there are virtually no management actions with regard to small-scale artisanal fisheries, perhaps due to a lack of interest on the part of the government, since such systems do not generate tax revenues, but also due to difficulties regarding the definition, identification and monitoring of these fisheries, considering their diffuse, multi-species nature. However, despite the artisanal quality, it is not unlikely that the target species of these fisheries are undergoing intensive pressure, as reported for the acoupa weakfish (Cynoscion acoupa), gillbacker sea catfish (Aspistor parkeri), Spanish mackerel (Scomberomorus brasiliensis), king weakfish (Macrodon ancylodon) and some cartilaginous fish (Carcharhinus porosus, C. acronotus and Dasyatis guttata) (Frédou \& Asano-Filho 2006). Considering the immeasurable labor involvement and the decline of many artisanal fisheries around the world (Pauly et al. 2002) as well as in the state of Pará (northern Brazil) (Bentes 2004), it seems evident that knowledge on the characteristics and dynamics of artisanal fisheries in this state is fundamental to the generation of information that could foster development measures for these activities as well as the protection of the species and ecosystems involved.

Multivariate comparison of the fishery production systems allows the detection of the need for differentiated management measures depending on the system in question. These approaches has gained much popularity using statistical comparative tools packages reducing monetary resources utilized in management process (Gavaris 2009, Hinz et al. 2009, Clarke et al. 2008).

The aim of the present study was to define, identify and characterize different fishery modalities along the coast of the state of Pará, Brazil, applying the concept of production systems, which allows typifying the fisheries that operate in the coastal and marine region of northern Brazil. This classification can contribute toward directing public policies regarding economic growth as well as environmental conservation measures and guide the sampling design for future collections in studies on ecology, biology, yield and fishery efforts that can be developed in the region.

\section{Material and Methods}

The northern coast of Brazil extends from Cabo Orange in the state of Amapá to São Marcos Bay in the state of Maranhão, covering a coastline distance of approximately $1300 \mathrm{~km}$. The area under the influence of the mouth of the Amazon River is occupied by a huge delta-estuarine complex that results in the mixture of approximately $6300 \mathrm{~km}^{3} /$ year of continental waters and $9.3 \times 108 \mathrm{t} /$ year of sediment in oceanic waters Barthem (1985). The coastal region is very unstable and is submitted to the action of processes that produce constant erosion and the depositing of sediments, which contributes toward the dynamic development of floodplains and a large number of islands. Mangrove forests occur in protected areas, helping to accentuate the irregularities of the coastline and generating broad tidal plains, which characterize what are known locally as the "Pará/Maranhão re-entrances" (Barthem 1985). All these peculiarities represent an extremely complex environment, which is reflected in the diversified regional fishing characteristics (Ceará 1988, Isaac 2006).

The marine/estuarine fishing fleet of the state of Pará is the most numerous and important of the Amazonian coast and operates throughout the entire northern region of the country (Pará 2010), with diverse types of vessels, such as skiffs with either sails or oars, motorized skiffs, small wooden motor boats ( 8 to $12 \mathrm{~m}$ ), medium-size wooden motor boats (12 to $20 \mathrm{~m}$ ) and steel industrial vessels with lengths surpassing $18 \mathrm{~m}$. For the purposes of data collection in the present study, fishing boats from nine municipalities in the state of Pará were considered between 2002 and 2005, involving the main landing sites and catch storage facilities in the state (Instituto... 2007): Vigia de Nazaré, Bragança, São Caetano de Odivelas, Marapanim, Curuçá, São João de Pirabas, Augusto Corrêa, Quatipuru and Soure (Figure 1).

For the delimitation of the fisheries, the concept of fishery production system was adopted, which is an extension of the concept of "métier" used by Mesnil \& Shepherd (1990) to classify multispecies fisheries. The difference in the present study was the inclusion of socioeconomic variables along with technical and environmental characteristics in the definition of the fisheries, the aim of which was to integrate the social and natural sciences in the definition of homogeneous units rather than limiting the study to the technical conception of fisheries generally employed by fishery researchers (Blanc-Pamard et al. 1992). Based on the concept determined among different researchers of the Brazilian RECOS Project (Millennium Institutes/CNPq), fishery production systems (FPS) were defined as a combination of social, economic, technological and environmental dynamics that has relatively homogeneous characteristics in terms of the organization of the work.

In order to obtain this classification, information from fishers and fisheries' stakeholders (community leader, union representatives and government agents) interviews at the landing sites as well as knowledge and experience of the research team were also incorporated. Moreover, secondary data were obtained from the scientific literature, when available.

Then, a list of categorization criteria was defined: 1-Fleet; 2-Fishing practices and gear; 3-Live resource exploited; 4-Target environment where exploitation occurs; 5- Fishermen's place of residence; 6- Fishermen's working relations; 7-Fishermen's income; 8-Degree of isolation from the community or location in which the fishermen live (Isaac et al. 2009). 


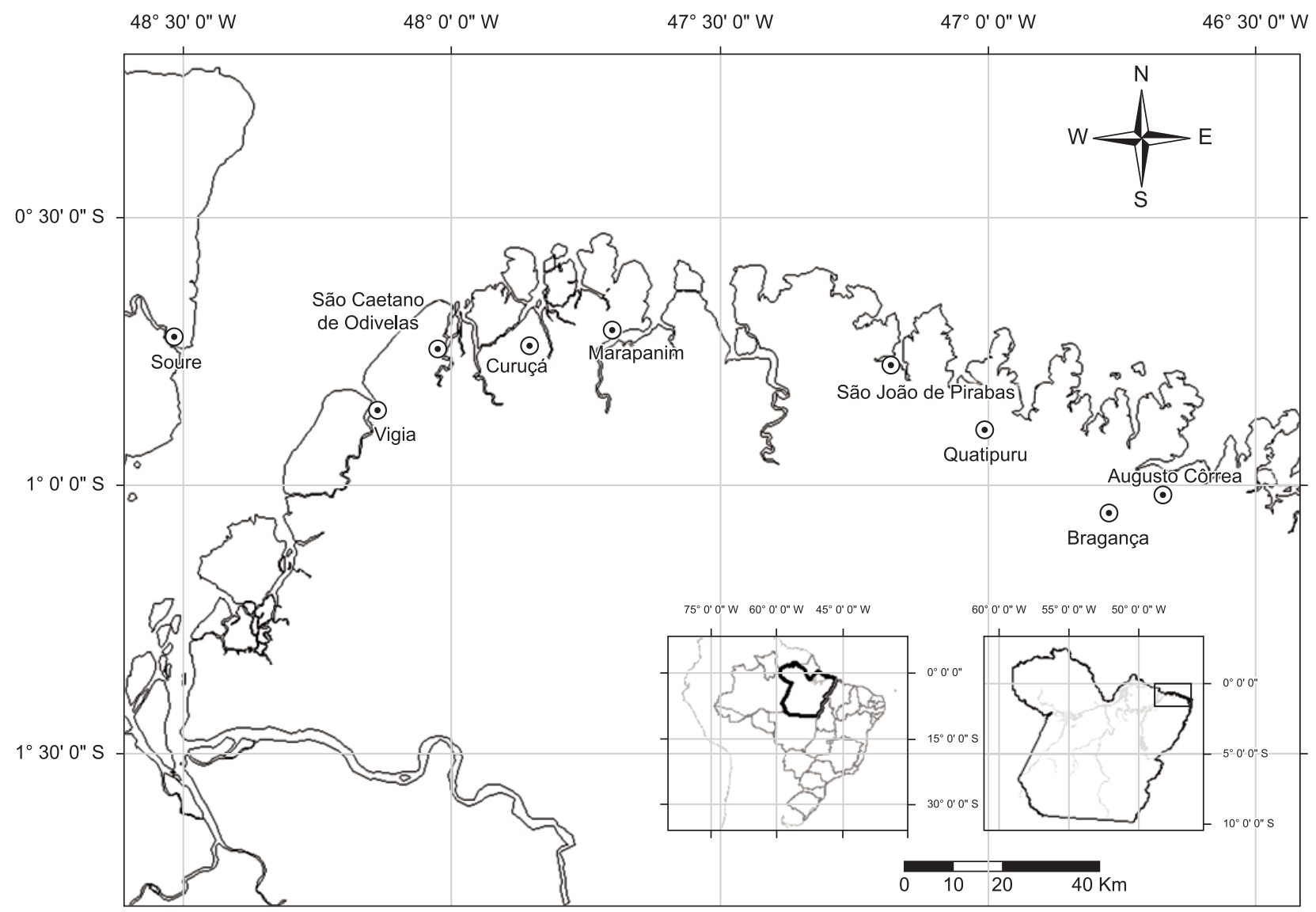

Figure 1. Main ports for landing of catches on the coast of the state of Pará (locations in bold type correspond to municipal administration centers).

Based on these criteria, the fishery production systems went through a more detailed assessment based on 57 attributes. These attributes were subdivided into five dimensions: social, economic, ecological, technological and political as multidisciplinary approach. The information was codified as ordinal variables, ranging from 1 to $3(4,5$ or 6 as maximum) in a first time (Table 1). The attributes of each system were hence scaled using the formulae $y=\frac{x_{\max }-x}{x_{\max }-x_{\min }}$.

A Ward cluster analysis with Euclidean distances was performed. In order to size down the number of systems, a similarity profile analysis (SIMPROF) was used to test groups significancy. Analyses were carried out in the $\mathrm{R}$ software environment with The $\mathrm{R}$ Stats Package (Stats; R Development Core Team 2011) and Significant Cluster Analysis package (clustsig; Whitaker \& Christman 2010).

\section{Results}

\section{Description of fishery production systems}

A total of 10 different groups of fishery production systems were identified operating along the Amazonian coast (Table 2) with fleets stationed in the state of Pará, two of which were industrial (AICS - Artisanal industrial continental shelf and IC - industrial coast) using steel-hull vessels of greater trip autonomy and fishing power. Four group systems were classified as large-scale artisanal systems (AC - Artisanal coast; ALC - Longline gillbacker sea catfish; AICS - Artisanal and industrial continental shelf) and ALO - Artisanal lobsters), having more developed technological attributed, although using wooden-hull vessels and fish conservation in ice compartments. More than half of the systems were classified as small-scale artisanal system, with catches performed with small vessels (at times without motors), conserving the catch in ice, when possible, and going on trips with a maximum of five days. The description of the main characteristics of each system is as follows:

- GROUP 1) Artisanal mangrove and beach : include Block net system (ABN), Shellfish (ASH), artisanal shrimps (ASR), sardine system (ASA) and net estuarine without engine boat (AEW). First fishing modality is banned by law. Fish are caught in tide channels and streams of the estuarine systems and this modality can be considered subsistence fishing. A small net with a fine mesh is secured to the bottom of the channel during low tide. At high tide, the net is stretched to the surface, where it is also tied. The net remains in the water for one tide cycle and is then searched. The nets may be deployed with the aid of a rowboat or occasionally with no vessel at all. Juveniles of species of commercial importance are caught, such as the acoupa weakfish (Cynoscion acoupa) and goliath grouper (Epinephelus itajara), as well as small adult fish, such as Cathorops sp., Mugil sp. or Sciades herzbergii, which use the channels and mangrove ecosystem as refuge, nursery and feeding ground. The system is very simple and offers little economic yield. Trips correspond to a single day, occupying two or three fishermen (generally relatives or friends), who live near the channels where the catches occur. Shellfish system employs men and women who collect mollusks, such as Mytella spp., Crassostrea sp., Neoteredo sp. and 
Table 1. Attributes used for the characterization of fishery production systems in the state of Pará considering five analysis dimensions (social, ecological, economic, technological and management).

Tabela 1. Atributos utilizados para a caracterização dos sistemas de produção pesqueira do Estado do Pará, considerando a análise de 5 dimensões (social, ecológica, econômica, tecnológica e de manejo).

\begin{tabular}{|c|c|c|}
\hline Dimension & Attribute & Description of classes \\
\hline \multirow[t]{10}{*}{ Social } & Professional indicators & 1 (bad) to 6 (excellent) \\
\hline & Working relationships & 1 - family/artisanal; 2 - boat owner; 3 - employee \\
\hline & Schooling & 1 (lower) to 3 (higher) \\
\hline & Origin of fishermen & $\begin{array}{c}1 \text { - locale; } 2 \text { - neighboring region; } 3 \text { - from the state, but far from } \\
\text { locale; } 4 \text { - out of state; } 5 \text { - abroad }\end{array}$ \\
\hline & Healthcare & 1 (bad) to 6 (excellent) \\
\hline & Social organization & $\begin{array}{l}\text { 1-non-existent; 2-exists, operates precariously; 3-exist, has little } \\
\text { community adhesion; 4-exists, has good community adhesion; } \\
\text { 5-high degree of community intervention, many members }\end{array}$ \\
\hline & Transportation and infrastructure & $\begin{array}{c}1 \text { - only by maritime/fluvial route; } 2 \text { - precarious land connections; } \\
3 \text { - good land connections }\end{array}$ \\
\hline & Housing location of fishermen & 1 - isolated locale; 2 - village; 3 - rural city; 4 - capital \\
\hline & Housing quality & 1 (bad) to 5 (excellent) \\
\hline & $\mathrm{n}^{\circ}$ of people exploiting the system & $\begin{array}{l}1 \text { - in decline; } 2 \text { - maintained stable over last } 5 \text { years; } \\
3 \text { - slight growth in last } r \text { years; } 4 \text { - accentuated growth in last } 5 \text { years }\end{array}$ \\
\hline \multirow[t]{15}{*}{ Ecological } & Degree of vulnerability & 1 (low) to 4 (high) \\
\hline & Primary productivity & 1 (oligotrophic) to 3 (eutrophic) \\
\hline & Degree of degradation & 1 (compromised), 2 (degraded) and 3 (conserved) \\
\hline & Changes in degree of degradation & 1 (worsening) to 3 (recovering) \\
\hline & Variation in habitat extension & 1 (rapidly reducing) to 4 (increasing) \\
\hline & Number of target species & 1 - mono-specific; 2 - multi to $10 ; 3$ - multi $>10$ \\
\hline & Variation in composition of target species & 1 - changes in species; 2 - changes in proportions; 3 - no changes \\
\hline & Average duration of life cycle & 1 - short; 2 - medium; 3 - long \\
\hline & Range of migration & 1 - inexistent; 2 local; 3 - regional; 4 - inter EEZ \\
\hline & $\begin{array}{c}\text { Variation in the extension of distribution of } \\
\text { fishery system }\end{array}$ & $\begin{array}{c}1 \text { - increasing; } 2 \text { - stable; } 3 \text { - slowing reducing; } \\
4 \text { - rapidly reducing }\end{array}$ \\
\hline & Vulnerability to reproduction & 1 (high) a 3 (none) \\
\hline & Vulnerability in cultivation area & 1 (high) a 3 (none) \\
\hline & Level of discards & 1 (high) to 4 (null) \\
\hline & Exploitation status & 1 (over-exploited) to 4 (under-exploited) \\
\hline & Changed in catch size & 1 - strong change; 2 - gradual change; 3 - no change \\
\hline \multirow[t]{9}{*}{ Technological } & Gear selectivity & 1 (low) to 3 (high) \\
\hline & Autonomy (days of trip) & $1(0-1) ; 2(2-5) ; 3(6-15) ; 4(16-30) ; 5(>30)$ \\
\hline & Product processing and conservation technology & 1 - none; 2 - exists, slightly sophisticated; 3 - very sophisticated \\
\hline & Localization and navigation technology & 1 (none) to 4 (high) \\
\hline & Evolution of fishing power & 1 - decreasing ; 2 - constant; 3 - increasing \\
\hline & Effect of gear & 1 - non-destructive; 2 - a little destructive; 3 - very destructive \\
\hline & Propulsion & $\begin{array}{c}1 \text { - on foot; } 2 \text { - rows; } 3 \text { - sail; } 4 \text { - motor up to } 20 \mathrm{hp} \\
5 \text { - from } 20 \text { to } 200 \mathrm{hp} ; 6 \text { - over } 200 \mathrm{hp}\end{array}$ \\
\hline & Communication system & 1 - none; 2 - some range; 3 - long range \\
\hline & Evolution of fishing effort & 1 - decreasing; 2 - constant; 3 - increasing \\
\hline \multirow[t]{11}{*}{ Economic } & Average catch price $(\mathrm{R} \$ / \mathrm{kg})$ & $1(0-2) ; 2(3-6) ; 3(7-15) ; 4(16-30) ; 5(\geq 30)(1 \mathrm{US} \$=1.758)$ \\
\hline & Average production per year $(\mathrm{kg})$ & $\begin{array}{c}1(0-100) ; 2(101-1000) ; 3(1001-10,000) \\
4(10,001-100,000) ; 5(>100,001)\end{array}$ \\
\hline & Aggregation of valor & 1 (low) to 3 (high) \\
\hline & Per capita income comparison & 1 (lower) to 3 (higher) \\
\hline & Frequency of other activities & 1 - never; 2 - occasionally; 3 - regularly \\
\hline & Importance of other activity & 1 (low) to 3 (high) \\
\hline & Cost of equipment & 1 (high) to 4 (low) \\
\hline & Price variation rate & 1 (high) to 4 (low) \\
\hline & Product destination & 1 - local; 2 - regional; 3 - national; 4 - international \\
\hline & Subsidies to activity & 1 (many) to 3 (none) \\
\hline & Dependence on middlemen & 1 (high) to 4 (none) \\
\hline
\end{tabular}


Table 1. Continued..

\begin{tabular}{|c|c|c|}
\hline Dimension & Attribute & Description of classes \\
\hline \multirow{12}{*}{ Management } & Limitation in access to resource & 1 - free access; 2 - not very effective; 3 - very effective \\
\hline & Existence of points of reference & 1 - no; 2 - partially; 3 - completely \\
\hline & Traditional measures & 1 - no; 2 - some; 3 - many \\
\hline & Governmental measures & 1 - no; 2 - some; 3 - many \\
\hline & Human impact & $\begin{array}{c}1 \text { - no; } 2 \text { - partially diagnosed; } 3 \text { - diagnosed with mitigation action; } \\
\qquad 4 \text { - complete mitigation }\end{array}$ \\
\hline & Users represented & 1 - no; 2 - some; 3 - all \\
\hline & Existence of conflicts & 1 - yes, broken relations; 2 - yes, serious; 3 - yes, mild; 4 - none \\
\hline & Statistics & $\begin{array}{c}1 \text { - do not exist; } 2 \text { - partially collected; } 3 \text { - completely; } \\
4 \text { - reliable statistics; } 5 \text { - available }\end{array}$ \\
\hline & Scientific research & 1 - does not exist; 2 - exists, not utilized; 3 -utilized \\
\hline & Existence of reserves & 1 - no; 2 - established, not managed; 3 - established, managed \\
\hline & Institutionalized procedures & 1 - no; 2 - partially; 3 - satisfactorily \\
\hline & Supervision/Monitoring efficiency & 1 - does not exist; 2 - is not efficient; 3 - is efficient \\
\hline
\end{tabular}

Lucina pectinata, from the mud of the tide channels during low tide. Collection is performed manually, even though transport to the extraction site may be carried out in a skiff. The activity is carried out in a single period by teams of approximately four partners (generally neighbors or relatives). This activity is not constant. The periods of greater activity are at the end of the year and during vacation time in July, when the products are sold to tourists. The rest of the year, the production is destined for the consumption of the collectors' families, especially between fish harvests, or sold to middlemen. Economic yield is low - approximately $\mathrm{R} \$ 20$ per expedition per collector. Artisanal beach include Include sardine catches (ASA) and shrimps catches (ASR). The first system is relatively new and occurs on rowboats, small sailboats or motorized skiffs with up to seven $\mathrm{m}$ in length and motors with little power. A transparent nylon net $300 \mathrm{~m}$ in length with a fine mesh is placed in the water column in regions near the beach or entrances to channels in order to capture Cetengraulis edentulus and Anchovia clupeoides of the family Eugraulidae. The catch is performed in a single day by teams of three or four partners or relatives. Average production is approximately 40 to $50 \mathrm{~kg}$ per trip. The catch is landed on the beach, washed, eviscerated, decapitated, salted and sun dried. It is later sold to middlemen, who pay approximately $\mathrm{R} \$ 10$ per $\mathrm{kg}$. The fishermen who participate in this production system have a low average income and live mainly in the community of Ajuruteua in the city of Bragança. The second system unites different forms of small-scale fishing and is characterized by catches carried out in estuaries and coastal waters in the between-tide region, aimed at catching marine shrimp from the family Penaeidae, especially Litopenaeus schmitti. Various types of fixed nets are used, such as zangarias (fixed gill net on stakes), which are gillnets placed buried in a circle around a sand bank and raised by the effect of the tide; puçás de muruada (fixed beach seine), which are conical gillnets placed in channels or deeper sites on the coastline; puçás de arrasto (beach seine), which are conical gillnets with a fixed opening, operated manually near the coastline; and gillnets with a fine mesh, cast manually in the proximities of the coastline or from a small vessel. Catches are carried out in locations near the fishermen's residences or on the beaches of the coast. The fishermen sometimes spend a number of days in precarious shacks during fishing expeditions before returning to their communities. Shrimp are caught, together with a wide diversity of small fish used for the consumption of the fishermen's families. This modality is particularly important during the summer on beaches such as Marudá (Marapanim) or Ajuruteua (Bragança), where the shrimp is sold to restaurants for service to tourists. Otherwise, the production constitutes small quantities of shrimp, which are sold either salted or fresh to middlemen. The fishermen of this system have a low quality of life and insufficient per capita income as well as a low degree of schooling and little access to social services due to the isolation of their communities. Net estuarine without engine (AEW): This fishing modality is characterized by the use of very simple, small vessels moved by oars or sail power (no motor) that transport two or three fishermen. Fish are caught with small gillnets with mesh size ranging from 40 to $50 \mathrm{~mm}$ between opposing knots. The fishing grounds are near the communities in estuarine or coastal areas over muddy or muddy and sandy bottoms. Trips are short (from a few hours to 1 or 2 days) and occupy two or three fishermen. A wide variety of species are caught, especially the king weakfish, torroto grunt (Geniatremus luteus), mullet (Mugil sp.) and coco sea catfish (Bagre bagre). The fishermen live in fishing communities and participate in the activity with relatives or neighbors. Incomes are quite low, but little investment is needed to perform the activity.

- GROUP 2) Artisanal Estuary (AE): with four kinds of modalities of fisheries very similar - Net estuarine with engine - (AEE): this system uses motorized skiffs and small wooden both with little motor power that operate in coastal or estuarine regions over muddy and sandy bottoms, catching marine fish with gillnets with a mesh size ranging from 50 to $70 \mathrm{~mm}$ between opposing knots. Trips last one week, occupying three or four fishermen. Small fish are targeted, such as the king weakfish, Macrodon ancylodon, and sardines from the families Engraulidae and Clupeidae, caught either in the water column or on the bottom. The yield is approximately $500 \mathrm{~kg}$ per trip, which generates an income of up to $\mathrm{R} \$ 400$ per fisherman. The fishermen in this system reside in either isolated communities or in the centers of the municipalities where the landings occur. Work relations are informal, with partners or family members. Longline estuary - (ALE) This fishing system targets estuary fish 


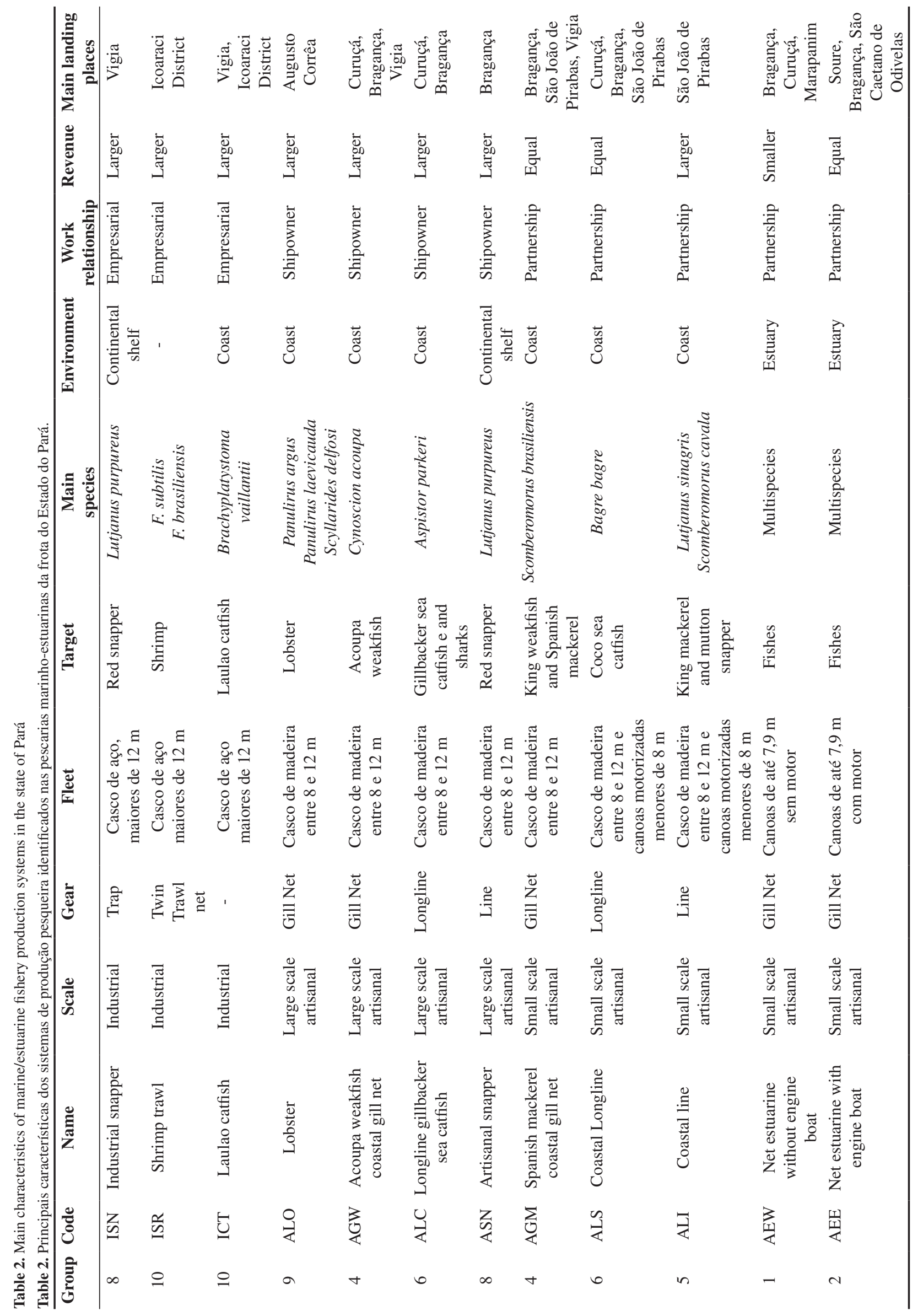




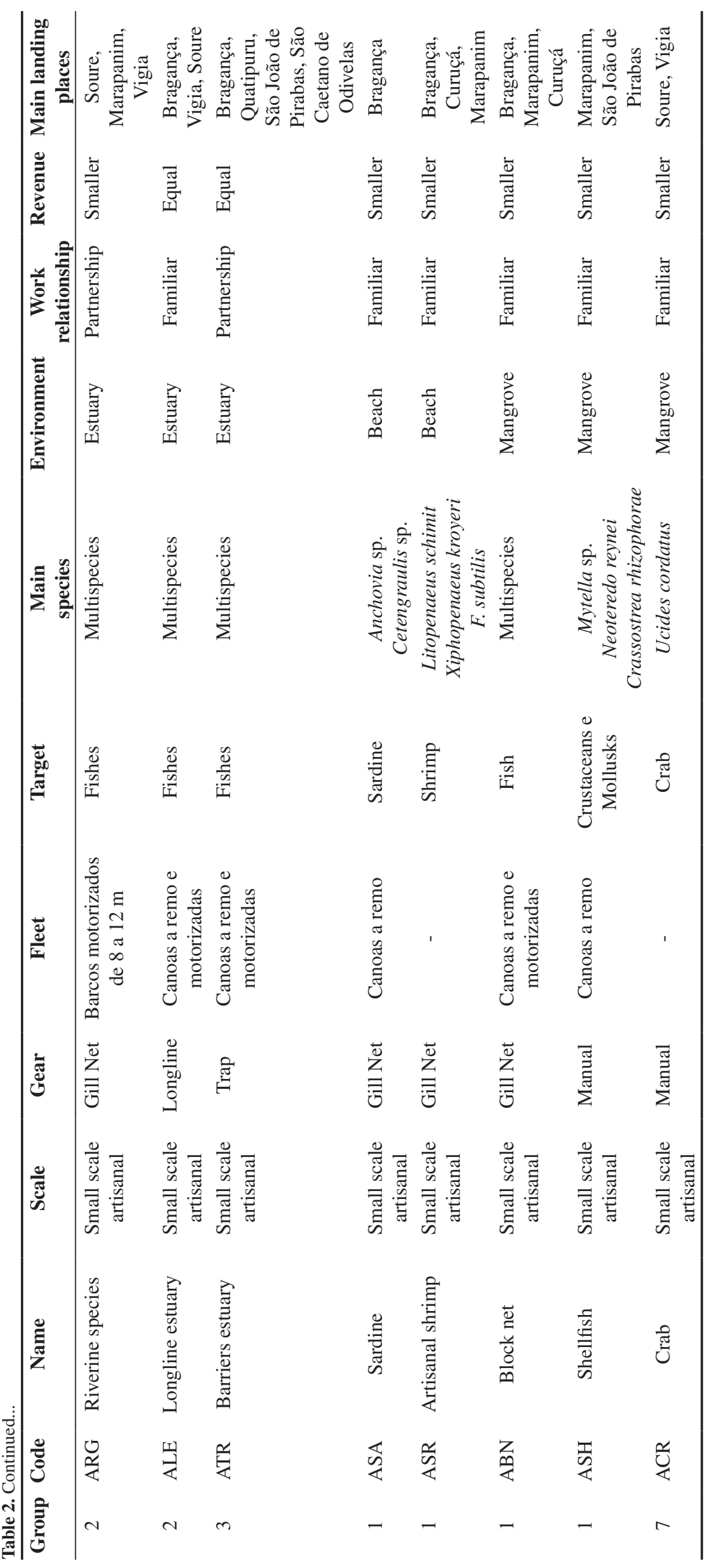


with bottom lines, using mainly small boats ( 8 to $12 \mathrm{~m}$ in length) with autonomy for less than one week and occupying three fishermen. The fleet operates in estuarine regions and sites near the coast. The most commonly used hooks are numbers 8 and 10 , which catch a large variety of species, especially catfish from the family Ariidae, such as the coco sea catfish, crucifix sea catfish and gillbacker sea catfish, which are generally maintained intact on board and sold immediately after landing. The fishermen in this system generally live in fishing communities near the landing sites and are relatively isolated from large urban centers. Catches are performed with friends or family members under informal work relations, splitting the profits, which can be up to $\mathrm{R} \$ 400$ per fisherman per trip. River gill net-(ARG) This system is dedicated to fishing freshwater species that occur in the waters of the Amazon estuary under the influence of the drainage of the Amazon River. Catches are carried out on small and mediumsize vessels with an average crew of five fishermen. Trips last approximately eight days and yield an average of $1.5 \mathrm{t}$ per trip. Gillnets are used, with three to five $\mathrm{Km}$ in length, five $\mathrm{m}$ in height and mesh size of $15 \mathrm{~cm}$ between opposing knots. The main species caught are freshwater fish, such as the laulao catfish, dolphinfish (Brachyplatystoma rousseauxii) and silver croaker (Plagioscion squamosissimus), but, depending on the season, some marine species are also caught, such as Sciades herzbergii. The fish are eviscerated and kept in ice in holds. Landings occur in large urban centers, especially in the city of Belém, but the fishermen may also live in smaller cities, such as Vigia or Marapanim. The production may be commercialized in the "See the Weight" market by middlemen or purchased by industries that perform processing and commercialization. The average yield per trip is $\mathrm{R} \$ 300$ per fisherman.

- GROUP 3) Barrier estuary - ATR: This fishery system is generalized along the coast of Pará and has considerable socioeconomic importance to the supply of fish for the local market. Traps or wooden barriers are used to catch fish, operating under the effect of the tide and locally called "corrals". The fish swims into the trap at high tide and is unable to find an exit. The traps are built in the betweentide region in areas of sufficient height in order to be either partially or completely uncovered at low tide for gathering the catch. To avoid competition, the fishermen consider the trap areas "private". The transport of the fishermen to the trap to gather the catch may be done on foot or in small vessels with or without a motor. A trip generally corresponds to a single tide cycle. The species most commonly found in these traps are Sciades herzbergii, Sciades proops, Bagre bagre (family Ariidae), Cynoscion sp., Mugil sp. (mullets) and Macrodon ancylodon (family Sciaenidae). The products are sold to middlemen and for the local market. The fishermen live in the proximity of the catch sites. Work relations are established through partnerships or with family members and, individual income is quite low.

- GROUP 4) Artisanal Coast: This group of system include acoupa weakfish coastal gillnet (AGW) and Spanish mackerel coastal gillnet (AGM): The first modality is carried out using motorized skiffs and boats of various sizes up to about $20 \mathrm{~m}$ in length, with multifilament nylon nets with meshes ranging from 15 to $20 \mathrm{~cm}$ between opposing knots. Net size depends on the size of the vessel, but can reach more than three $\mathrm{Km}$ in length and $5 \mathrm{~m}$ in height. The nets are placed in the water column in contact with the muddy-sandy substrate in coastal regions and on the continental shelf at depths down to $30 \mathrm{~m}$. Large specimens, such as the acoupa weakfish, Cynoscion acoupa
(Lacepède, 1801), and gillbacker sea catfish, Aspistor parkerii (Traill, 1832), are caught, along with other species with lesser frequency or lower economic importance, such as the crevalle jack - Caranx sp., crucifix sea catfish - Sciades proops (Valenciennes, 1840) and tarpon - Megalops atlanticus Valenciennes, 1847. Trips can last between 10 and 25 days, occupying four to 12 fishermen. The fish are eviscerated and conserved in the holds with ice. The yield per trip is proportional to the size of the boat and can reach $\mathrm{R} \$ 1000$ per fishermen in extreme cases. The meat is commercialized by middlemen for the regional and national markets. Moreover, the swim bladder is sun dried and sold to emulsifier industries and has a high international value. The second fishing modality that uses small wooden boats with medium motor power, operating gillnets with mesh size ranging from 40 to $60 \mathrm{~mm}$ between opposing knots, a height of four $\mathrm{m}$ and more than $1000 \mathrm{~m}$ in length. The net is deployed in coastal environments in the pelagic zone, but can reach the bottom, depending on the depth of the fishing ground. Trips may last a week and occupy about four fishermen, who work in a partnership system. The Spanish mackerel, Scomberomorus brasiliensis, is the main target species, but catfish (Bagre bagre), mullets (Mugil sp.) and other species of lesser economic importance are also caught. Landings occur with more intensity in the municipalities of São João de Pirabas and Vigia. The catch is commercialized by middlemen for the national market. One trip yields a maximum of R\$ 400 per fisherman.

- GROUP 5) Coastal line (ALI): This system uses small boats with little motor power and holds with ice for the catch of species in the coastal region over muddy bottoms with a bottom longline containing 500 hooks. The most caught species is the coco sea catfish, Bagre bagre (Linnaeus, 1766), but species from the families Ariidae and Sciaenidae are also caught. Trips last an average of four days, with a crew of four fishermen. Production can be just over one ton per trip. The fishermen are from the state of Pará or states in northeastern Brazil and live in either the urban centers of the municipalities or fishing communities. Work relations are established between family members and friends. The boat owner splits the profit with the fishermen, who receive an average of $\mathrm{R} \$ 100$ per trip.

- GROUP 6) Longline gillbacker sea catfish - ALC and Coastal longline - ALS: Fishery that uses small and medium-size wooden boats with motors of medium power that operate bottom longlines $2000 \mathrm{~m}$ in length with approximately 3000 hooks that are deployed in coastal environments over muddy substrates. Trips last about 15 days, occupying an average of eight fishermen. Mean production per trip is seven to eight tons. The gillbacker sea catfish, Aspistor parkeri, is the main target, but Cynoscion acoupa, Cynoscion sp. and Caranx sp. are also caught. The fish are eviscerated on board and conserved in ice in the holds. Besides the meat, the swim bladder of the gillbacker sea catfish has high economic value and is destined for the external market. The work relations have the fishermen subordinated to the boat owners, who divide the profits in parts. Coastal longline - ALS: This fishing modality employs motorized skiffs and small boats with little motor power, operating handlines with two hooks baited with shrimp or sardine. Trips last approximately six days, occupying four fishermen. The main target species are the king mackerel, Scomberomorus cavalla, and yellowtail snapper, Lutjanus analis, which are alternated in their respective seasons. Catches are carried out in the water column in fishing grounds located in the coastal region. Other species of lesser 
commercial value are also caught, such as Megalops atlanticus. The fish are eviscerated and kept in ice in holds. The fishermen work with partnership relations for the activity. One trip can yield up to one ton of catch, which generates about $\mathrm{R} \$ 500$ per fisherman, but the boat owner receives a greater proportion of the profit. The catch is sold to middlemen and may be sent to other states in the country.

- GROUP 7) Crab - ACR: This production system consists of the manual collection of the mangrove crab Ucides cordatus, which inhabits dens in the mud of mangroves. In the rainy season, when the crabs are deeper in their dens, the catch is performed by arm or by introducing a hook into the den. In the dry season, a nylon bow attached to a stick may also be used, which is placed in the entrance to the den to catch individuals that come out during low tide. In some municipalities, such as Soure, São Caetano de Odivelas, Bragança and Vigia, this production system has considerable socioeconomic importance in terms of both the production volume and the enormous contingent of fishermen involved. Commercialization is performed either in natura in regional markets or processed for middlemen and supermarkets. The catches are performed by men, but women participate in the processing for the obtainment of the claw and meat, which has a high commercial value. Crab diggers are a marginalized social group due to their low income, low degree of schooling and under-recognition among the fishermen of other modalities. Their residences are near the collection sites, which they reach by skiff, on foot or by bicycle in small groups of neighbors or relatives.

- GROUP 8) Artisanal and Industrial Continental Shelf (AICS): This group include Industrial and artisanal snapper catches (ISN and ASN). The first is dedicated to catching snapper and includes several species of the family Lutjanidae, especially Lutjanus purpureus (Poey, 1866). Catches occur on industrialscale vessels with powerful motors (average of $375 \mathrm{Hp}$ ) that have refrigerated chambers for freezing the catch. Trips last approximately ten day and occupy ten fishermen. The vessels operate mainly over consolidated bottoms on the continental shelf between depths of 90 and $110 \mathrm{~m}$ off the northernmost coast of Brazil. Approximately 10 traps are used per vessel. The trap is made of steel, with a $6 \mathrm{~cm}$ mesh, $30 \mathrm{~cm}$ mouth opening and a base $4 \mathrm{~m}$ in diameter and $1.6 \mathrm{~m}$ in height. Landings are generally performed in the city of Vigia. As a modality originating in northeastern Brazil, where resources have since become scarce, a large portion of the fishermen hail from this region and currently live in urban centers such as Vigia or Belém. The fishermen often have stable work relations, as many are employees of the fishing firms, and their income is also considered high in comparison to other production systems. The second snapper catches on an artisanal scale are carried out on medium-size and small wooden-hull vessels that use snapper lines, which are longlines with several hooks. There are two forms of operating these lines: i) deployment and retrieval from the boat, with the help of a ratchet system denominated "the bicycle"; and ii) deployment from a small kayak or skiff operated by a single fisherman. In the latter modality, the mother vessel transports a number of skiffs to the catch site, which are then launched with their respective fishermen. After the catches, the skiffs return to the mother vessel, which has holds where the catch is eviscerated and conserved in ice. Trips last more than 10 days, occupying approximately nine fishermen. The workers in this modality mainly reside in the city of Bragança, where most of the landings occur. Some workers are contracted by boat firms and have working papers; others work in a partnership system, in which the boat owner is responsible for the commercialization of the products. Due to its importance in the international market, snapper catches, even those of an artisanal nature, result in good economic yields, but the fishermen in this modality have a lower income than those in the industrial fisheries.

- GROUP 9) Lobster - ALO: Lobster catches (Panilurus argus, P. laevicauda and Scyllarides delfosi) are carried out by small and medium-size wooden boats with relatively powerful motors and autonomy for trips lasting more than one month, occupying about six fishermen. These vessels mainly operate long gillnets without much height, locally called caçoeiras (bottom driftnet), which are left to drift over the substrate. Steel or wooden traps are occasionally employed. The fishing areas are located on the continental shelf over consolidated bottoms. The lobsters are decapitated on board. The meat from the head and the tail are bathed in sodium metabisulfite and conserved in ice until landing. Landings mainly occur at ports in the cities of Augusto Corrêa and Bragança. This fishery was introduced in the state of Pará only in the 1990s, with the migration of part of the fleet that operated on the northeastern coast of Brazil. Thus, nearly all the lobster fishermen hail from states in the northeastern region who moved to take up residence in the cities in which the landings are currently performed. Ownership of the boats is concentrated in the hands of few individuals, who pay the fishermen based on the yield of the trip and the function of each worker. Lobster catches can result in up to one ton of tails per trip, which, after the split, result in an income of approximately $\mathrm{R} \$ 400$ (US\$230) per fisherman.

- GROUP 10) Industrial coast (IC) with Laulao catfish catches ICT: Catches of the laulao catfish, Brachyplatystoma vaillantii (Valenciennes, 1840), take place with the use of either woodenhull or steel-hull vessels with powerful engines (average of $425 \mathrm{Hp}$ ), which operate bottom trawl nets with a $150 \mathrm{~mm}$ mesh in the sleeve, $60 \mathrm{~mm}$ mesh in the bag and $70 \mathrm{~mm}$ mesh in the funnel of the net, operated with paired vessels (one net is trawled by two boats). Catches occur on muddy bottoms in the mouth of the Amazon River and throughout the Amazon estuary. The distance from the coast depends on the season of the year and displacement of the stretch of brackish waters due to alteration in the runoff of the hydrographic basin. Trips last approximately one week and occupy an average of five to seven fishermen. The catch is conserved in ice in the holds of the boat, which can transport as many at $40 \mathrm{t}$. The fishermen have relatively good professional indicators. Most are employees of the fishing firm and they generally live in urban centers in the state. Mean income of the workers of this modality may be considered relatively good in comparison to other fishing modalities. Industrial shrimp - ISR: This system is dedicated to the capture of shrimp from the family Penaeidae, especially Farfantepenaeus subtilis (Pérez-Farfante, 1967), on the continental shelf between the states of Maranhão and Amapá in regions with muddy and sandy bottoms, with the best yields obtained in the extreme northern portion of the fishing ground. Catches take place on large steel-hull vessels of considerable power, which operate twin bottom trawl nets. These vessels have navigation equipment and refrigerated chambers for freezing the catch. Trips can last more than 45 days, occupying five or six fishermen. The shrimp are washed, decapitated and immersed in a sodium metabisulfite bath prior to freezing. The fishermen who work with this modality have good residences, generally located in the state capital, and have better socioeconomic indicators. Most are employed by the fishing firms that own the vessels and therefore have more 
stable work relations that ensure social benefits. This is one of the most lucrative activities in the region. One fishing trip may generate up to 10,000 American dollars in profit. The fishermen received a fixed salary per trip plus a bonus, which depends on the yield.

\section{Comparison between fishery production systems}

The multidimensional scaling analysis clearly reveals the arrangement of the fisheries in a horizontal gradient based on scale: i) small-scale artisanal; ii) large-scale artisanal; and iii) industrial (Figure 2). The cluster analysis demonstrates that the percentage of dissimilarity was low in some cases among the 20 fishery production systems identified, revealing that, although they have different fishing typologies, the attributes used did not exhibit considerable distancing between some of the systems. Thus, 10 significantly different fishery typologies were identified (SIMPROF test $\mathrm{p}<0.05$ ) (Figure 3 ). Among these groups, there are systems

with similarities to one another:

- Group 1) Artisanal sardine (ASA), artisanal shrimp (ASR) nearly all the criteria are similar, except the target species and manual collection of mollusks. Fisheries are carried out with barrier nets and net estuarine without engine system, which are performed in similar environments and have very similar work relations, economic yields and degree of isolation of the fishermen's communities;

- Group 2) Small-scale artisanal catches carried out in estuaries (ALE, AEE and AEW) - although these systems employ different gear, such as nets and longlines, there are substantial similarities related to the diversity of the fish caught and work relations;

- Group 3) The artisanal trap (ATR);

- Group 4) The artisanal Spanish mackerel (AGM) and artisanal acoupa weakfish (AGW) - operate with gillnets in coastal waters with fishermen who inhabit communities near urban centers;

- Group 5) Coastal line (ALI);

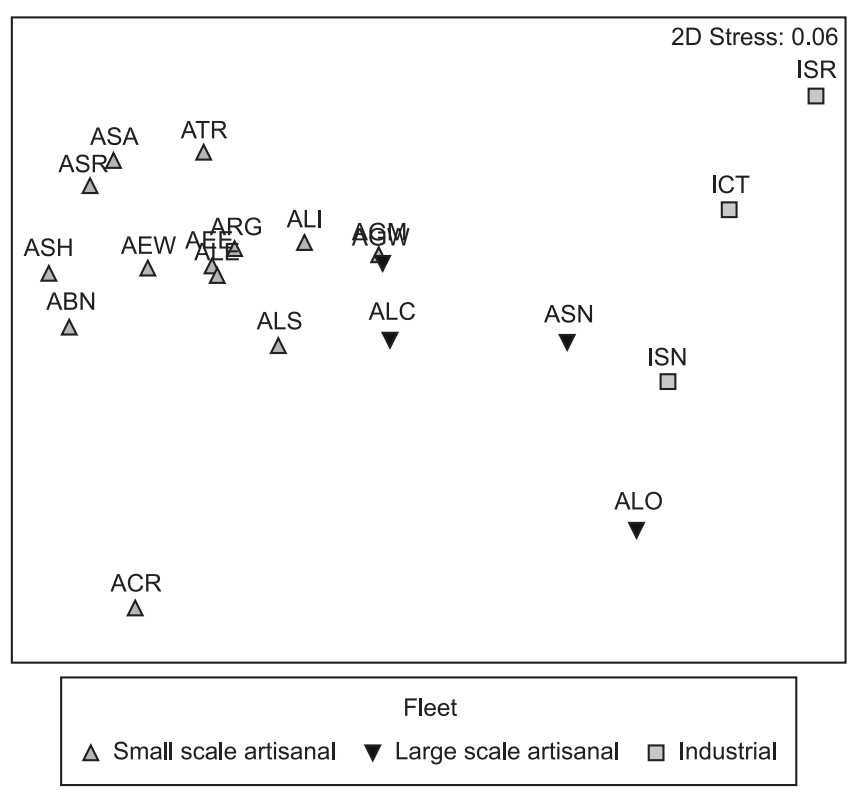

Figure 2. Multidimensional scaling of similarity profile of fishery production systems in the state of Pará, featuring the 12 groups described
- Group 6) Coastal longline (ALS) and longline gillbacker sea catfish (ALC)- operate with longlines in coastal waters but have different target species;

- Group 7) Crab (ACB);

- Group 8) Industrial snapper (ISN) and large-scale artisanal snapper (ASN) - target the same species and have similar yields, environments and locations of fishermen's residences;

- Group 9) Lobsters (ALO);

- Group 10) Industrial shrimp (ISR) and laulao catfish (ICT) operate with similar gear (seine) and involve fishermen that inhabit urban centers and have greater economic yields;

Conversely, the artisanal trap (ATR), coastal line (ALI), crab (ACR - Group 7) and lobster (ALO) systems, remained individually separated due to their clear differences, especially with regard to target species and gear.

\section{Discussion}

The different fishing modalities should be considered from a more holistic and hierarchical perspective (Sinclair et al. 2002, De La Mare 2005) in order to gain a substantial understanding of their dynamics. This understanding goes beyond the simple distinction between categories and includes different ways of considering long-term sustainability.

Due to its economic and social representativeness, fishing on the coast of the state of Pará is one of the most important traditional activities of the entire region. It complexity is reflected in the development of diverse subunits, denominated fishery production systems. These systems have more or less homogeneous structures and particular technological, economic and social characteristics, which makes them the object of possible specific management measures. Fishery production systems have been implicitly proposed by Paiva (1997), who described landing volumes of fisheries in northern Brazil, dividing the modalities based on target species. However, the classification proposed here has a broader scope, particularly with regard to the subdivision of the fishery systems of an artisanal nature, as this resulted in a combination of various ecological, technological and socioeconomic attributes and consequent statistical validation.

The proposed classification also allows determining the existence of an increasing scale gradient of the fisheries, which can be measured by the degree of technological development, fishing capacity and power, area of operation and production obtained on the trips. Nery (1995) stresses the existence of a series of small-scale fishery production systems in northern Brazil that work with relatively simple, traditional methods. Barthem \& Fabré (2004) typify four large fishing areas on the northern coast: 1- northern coast, off the state of Amapá; 2- Amazon Delta, mouth of the Amazon River; 3Marajó Bay, mouth of the Pará River; and 4-Salgado Paraense, in the northeastern region of the state of Pará. This indicates that the area of operation is correlated to boat size and hold capacity. Larger vessels travel to the northernmost point of Brazil, whereas smaller vessels remain between Marajó Island and the coast of Salgado. The same type of gradient can be detected in the present study, as social and economic indicator values increase with the increase in the scale of the fishery system and its importance in the consumer market, which runs from exportation among industrial fisheries to the regional and national markets among artisanal fisheries of greater economic importance and the local market and subsistence fishing among small-scale artisanal fisheries.

The delimitation of 20 fishery systems is clear and easily distinguished when considering each system individually. However, when compared, some typologies resemble one another in their 


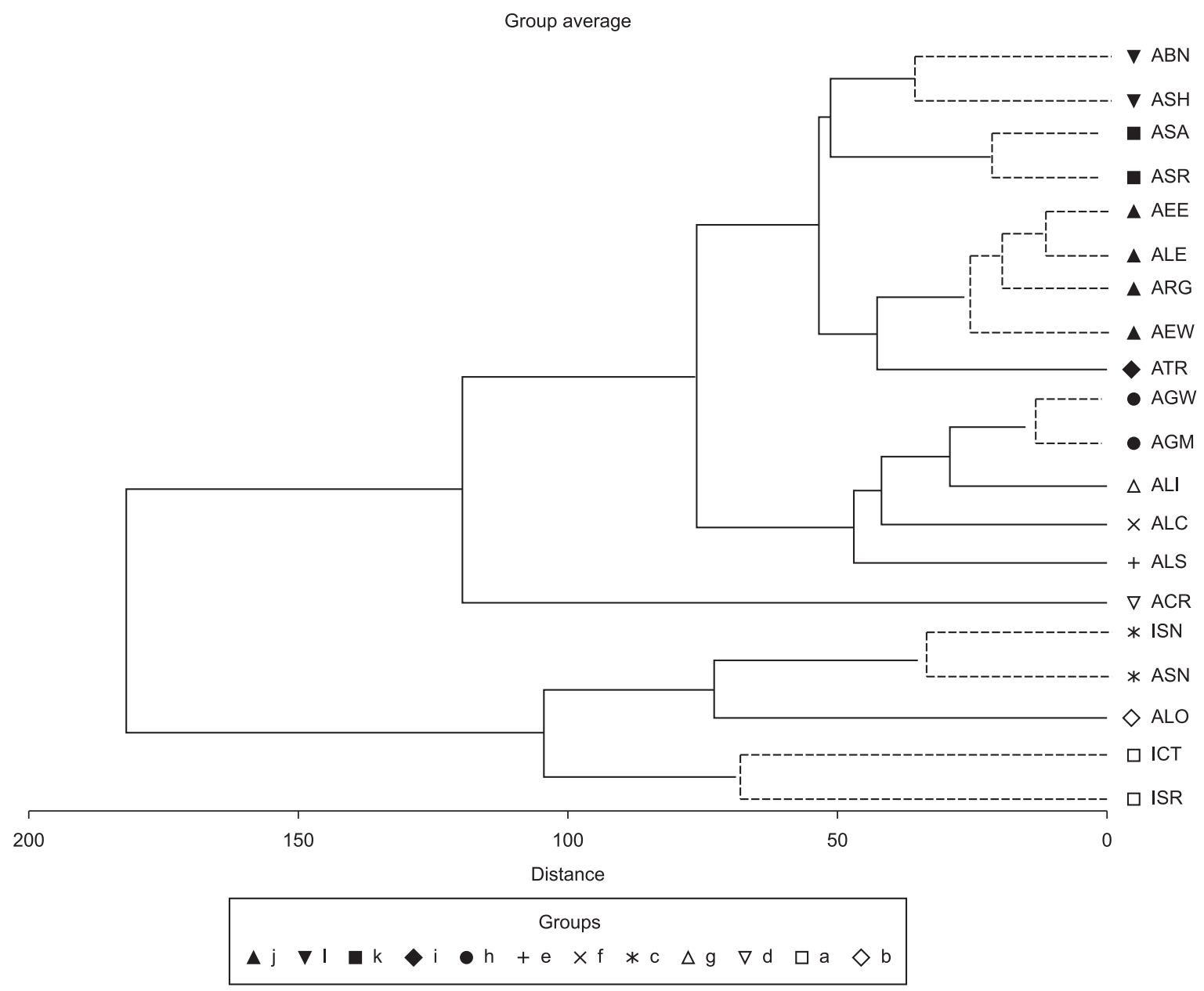

Figure 3. Distribution and clustering of fishery production systems on the coast of Pará; dotted lines refer to systems in which no striking differences were detected in the similarity profile (SIMPROF) and dissimilarities were less than 9\%; letters on the left of the dendogram correspond to the 12 groups identified.

attributes, which makes the validation methods of the systems not detect these differences and leads to convergence to ten groups.

The complexity of the productive arrangement and situation of collapse of some fishery production systems in the state of Pará, such as industrial shrimp fishing (Isaac et al., 2009) and, more recently, both artisanal and industrial snapper (Souza 2002), denote the need for more adequate management in order to ensure the long-term sustainability of these catch modalities. Management measures should be concise and coherent to the peculiarities of the systems established here. Thus far, most management measures have focused on industrial fishery systems, even though there is an evident predominance of artisanal systems in northern Brazil (Isaac et al. 2009) and even considering the fact that the equipment of and incentives for industrial fleets are far from comparable to other industrial fleets in the country (Isaac et al. 2006). Including the shrimp, snapper, laulao catfish and lobster fleets as industrial fisheries, the catch volumes for these fisheries total an average of $20 \%$ of the annual production of marine/ estuarine origin in the state (Isaac et al. 2006, 2009). This further stresses the importance of medium-scale and small-scale artisanal systems, along with the need to pay more attention to the management of these modalities.

The negligence of the fishery management authorities with regard to artisanal modalities in northern Brazil is indisputable. Incentive policies have concentrated on measures regarding financing, low interest rates, fishing gear and vessels and have been executed without the due monitoring of their impact. The result of this is a large number of defaulted loans among those who owe payments on this financing and, consequently, a lack of financial resources on the part of the state for further incentives.

This 'developmentalist' vision on the part of the government does not take into consideration the specific characteristics of each fishing modality. It seems evident that subsistence and small-scale systems, which have low economic yields, should receive incentives for improving the living conditions, education and social organization of the fishermen, seeking an increase in social indicator values, independently from changing the traditional forms of exploiting resources.

For industrial and semi-industrial fisheries, such as those that use trawl nets (shrimp and laulao catfish), and those targeting snapper and lobster, alternative forms of income should be prepared, along with a radical reduction in effort, as stocks are at their maximal levels of exploitation (Frédou \& Asano-Filho 2006, Isaac et al. 2009).

Large-scale artisanal fisheries, such as those targeting the Acoupa weakfish and Spanish mackerel, are in a process of full development. Thus, the most adequate directive in these cases is the control of the fishing effort, along with an improvement in the quality of the catch and forms of commercialization in order to assist each modality in accordance with its main characteristics. Moreover, the organization of the fishermen should be enhanced so that they may take on greater responsibility in sharing in the decision making process with regard to management measures. 
The subdivision of the marine/estuarine fishery systems of northern Brazil proposed here should assist in the management of resources and should be taken into consideration when deciding what measures should be adopted for the sustainable management of the fishing modalities based on their particular characteristics.

\section{Acknowledgements}

This study was completely supported by CNPq - National Research Council - Millennium Institute - Coastal Resources RECOS for funding and through a research grant to the last author (308421/2010-8). The authors would like to thank Richard Boike for translating this paper into English and his helpful manuscript comments and the anonymus referees for comments on earlier drafts of the manuscript.

\section{References}

BARTHEM, R.B. 1985. Ocorrência, distribuição e biologia dos peixes da Baía do Marajó, Estuário Amazônico. Bol. Mus. Para. Emílio Goeldi 2(1):4969.

BARTHEM, R.B. \& FABRÉ, N.N. 2004. Biologia e diversidade dos recursos pesqueiros da Amazônia. In A pesca e os recursos pesqueiros na Amazônia brasileira. (M. L. Ruffino, ed.). IBAMA/ProVarzea, Manaus, p.17-63.

BENTES, B.S. 2004. Diagnóstico da pesca no litoral paraense. Dissertação de mestrado, Universidade Federal do Pará, Belém.

BLANC-PAMARD, C., DEFFONTAINES, J.P., FRIEDBERG, C. 1992. Techniques et pratiques: à la jonction du naturel et du social. In Sciences de la nature, sciences de la societé (M. Jollivet). CNRS Éditions, Paris, p.347-355.

BRAGA, C.F. 2002. A atividade pesqueira de larga escala nos portos de desembarque do estuário do rio Caeté, Bragança-PA. Dissertação de Mestrado, Universidade Federal do Pará, Belém.

BRASIL. Ministério do Meio Ambiente, dos Recursos Hídricos e da Amazônia Legal - MMA. 1997a. Diretrizes ambientais para o setor pesqueiro. MMA, Brasília, 124p.

BRASIL. Ministério do Meio Ambiente, dos Recursos Hídricos e da Amazônia Legal - MMA. 1997b. Levantamento do estado da arte da pesquisa dos recursos vivos marinhos do Brasil. Recursos pesqueiros. MMA, Brasília, 241p. Programa REVIZEE.

CEARÁ (Estado). Superintendência do Desenvolvimento da Pesca - SUDEPE. 1988. Diagnóstico da pesca do Estado do Ceará. Fortaleza, 176p.

CLARKE, K.R., SOMERFIELD, P.J. \& GORLEY, R.N. 2008. Testing of null hypotheses in exploratory community analyses: similarity profiles and biota-environment linkage. J. Exp. Mar. Biol. Ecol. 366:56-69. http:// dx.doi.org/10.1016/j.jembe.2008.07.009

DE LA MARE, W.K. 2005. Marine ecosystem-based management as a hierarchical control system. Mar. Policy 29(1):57-68. http://dx.doi. org/10.1016/j.marpol.2004.02.002

ESPÍRITO-SANTO, R.V. 2002. Caracterização da atividade de desembarque da frota pesqueira artesanal de pequena escala na região estuarina do rio Caeté, município de Bragança-Pará-Brasil. Dissertação de mestrado, Universidade Federal do Pará, Belém.
FRÉDOU, F.L. \& ASANO-FILHO, M. 2006. Recursos Pesqueiros da Região Norte. In Programa REVIZEE - Relatório Executivo. (S. Jablonski, C.L.D.B. Rossi-Wongtschowski, M. Haimovici, R.P. Lessa, A. Martins, R. Ávila \& F.L. Frédou). Ministério do Meio Ambiente, Brasília, p.121-152.

GAVARIS, S. 2009. Fisheries management planning and support for strategic and tactical decisions in na ecosystem approach context. Fish. Res. 100(1):6-14. http://dx.doi.org/10.1016/j.fishres.2008.12.001

HINZ, H., PRIETO, V. \& KAISER, M.J. 2009. Trawl disturbance on benthic communities: chronic effects and experimental predictions. Ecol. Appl. 19(3):761-773. PMid:19425437. http://dx.doi.org/10.1890/08-0351.1

INSTITUTO BRASILEIRO DO MEIO AMBIENTE E DOS RECURSOS NATURAIS RENOVÁVEIS - IBAMA. 2007. Estatística da Pesca 2005. Brasil. Grandes regiões e estados da federação. IBAMA, Brasília. http:// www.ibama.gov.br/recursos_pesqueiros

ISAAC, V.J., SANTO, R.V.E., BENTES, B.B., CASTRO, E. \& SENA, A.L. 2006. Diagnóstico da pesca no litoral do Estado do Para. In A pesca marinha e estuarina do Brasil no início do século XXI: Recursos, tecnologias, aspectos socioeconômicos e institucionais (V.J. Isaac, A.S. Martins, M. Haimovici \& J.M. Andrigetto Filho, eds.). Universidade Federal do Pará, Belém, p.11-33.

ISAAC, V.J., SANTO, R.V., BENTES, B.S., FRÉDOU, F.L., MOURÃO, K.R. \& FRÉDOU, T. 2009. An interdisciplinary evaluation of fishery production system of the State of Pará in North Brazil. J. Appl. Ichthyol. 25(3):244255. http://dx.doi.org/10.1111/j.1439-0426.2009.01274.X

ISAAC, V.J. \& MARTINS, A. 2003. Uso e apropriação de recursos costeiros, Modelo gerencial da pesca - MGP: relatório de resultados. Porto Alegre. 20 p. Mimeo.

MESNIL, B. \& SHEPHERD, J.G. 1990. A hybrid age-structured and lengthstructured model for assessing regulatory measures in multiple-species, multiple-fleet fisheries. J. Cons. - Cons. Int. Expl. Mer. 47:115-132.

NERY, A.C. 1995. Traços da tecnologia pesqueira de uma área de pesca tradicional na Amazônia - Zona do Salgado - Pará. Bol. Mus. Para. Emílio Goeldi 11(2):199-293.

PAIVA, M.P. 1997. Recursos pesqueiros estuarinos e marinhos do Brasil. UFC, Fortaleza.

PARÁ (Estado). Secretaria de Estado de Pesca e Aquicultura- SEPAQ. 2010. Apresentação de estatística pesqueira 2008. www.sepaq.pa.gov.br (último acesso em: 25/05/2010).

PAUly, D., CHRISTENSEN, V., GUÉNETTE, S., PITCHER, T.J., SUMAILA, U.R., WALTERS, R.W. \& ZELLER, D. 2002. Towards sustainability in world fisheries. Nature. 418: 689-695. PMid:12167876. http://dx.doi.org/10.1038/nature01017

R DEVELOPMENT CORE TEAM. 2011. R: A language and environment for statistical computing. R Foundation for Statistical Computing, Vienna, Austria. http://www.R-project.org/

SINCLAIR, M.,ARNASON, R., CSIRKE, J.,ZARNICKI,Z., SIGURJONSSON, J., RUNE SKJOLDAL, H. \& VALDIMARSSON, G. 2002. Responsible fisheries in the marine ecosystem. Fish. Research. 58(3):255-265. -

SOUZA, R.F.C. 2002. Dinâmica Populacional do Pargo Lutjanus purpureus, Poey, 1875 (Pisces Lutjanidae) no Norte do Brasil. Dissertação de Mestrado, Universidade Federal do Pará, Belém.

WHITAKER, D. \& CHRISTMAN, M. 2010. clustsig: Significant Cluster Analysis. R package version 1.0. http://CRAN.R-project.org/ package $=$ clustsig 